\title{
POZŮSTATKY MONTÁNNÍ ČINNOSTI SPOJENÉ S PROSPEKCÍ LOŽISKA ZLATA V MÍSTECH ZANIKLÉHO STŘEDOVĚKÉHO MĚSTEČKA
}

\author{
PETR NOVÝ
}

Abstrakt: Ve 13. století bylo nad soutokem Vltavy a Sázavy v těsné blizkosti Ostrovského kláštera založeno remeslnické městečko. Předpokládá se, že jeho zhruba třicetiletou existenci ukončil vpád Braniborů, po němž městečko zůstalo v troskách a nebylo v žádném rozsahu obnoveno. Revize hlášení a nálezových zpráv archeologického výzkumu, probíhajícího v minulém století, však odhaluje celou řadu zajímavých detailü, kterými lze dosavadni pohled na historii městečka korigovat. Jedno ze zjištěni vedlo k nové interpretaci tzv. zásobnicových jam, nacházejících se zejména na východním svahu ostrožny, predstavujících doklady hornické činnosti. Z polohy objektů a minimálně jednoho druhotného využití lze alespoň jejich část datovat do obdobi pred vznikem pravidelného půdorysu městečka.

Klíčová slova: 13. století-Sekanka - Jablonná - těžba zlata-lokační sídliště - hornické sídliště.

Traces of mining activities connected with the prospection for gold on the site of a deserted medieval town

Abstract: A craftsmen's town was established in the 13th century above the confluence of the Vltava and Sázava rivers, in close proximity of the Ostrov Monastery. It is presumed that it existed for approximately thirty years and was wiped out by the invasion of Brandenburg troops which left the town in ruins; it was never restored in any form. However, the revision of records and find reports from excavations taking place in the last century brought to light a number of interesting details which modify the existing view in the town's history. One of the findings led to a new interpretation of storage pits located, in particular, on the eastern slope of the promontory and confirming mining activities. Based on the location of these features and at least one example of secondary use, part of them can be dated to the period before the origination of the town's regular ground plan.

Key words: 13 th century - Sekanka - Jablonná-gold mining - location settlement-miners' settlement.

V souvislosti s výzkumem starých cest $\mathrm{v}$ blízkosti pojednávané lokality byla nedávno předložena hypotéza o ztotožnění archeologicky zkoumaného sídliště označovaného jako Sekanka s písemnými prameny doloženým městečkem Jablonná (Nový 2016; obr. 1). Při snaze revidovat výsledky výzkumu a datování nálezů byla zaznamenána přítomnost terénních situací

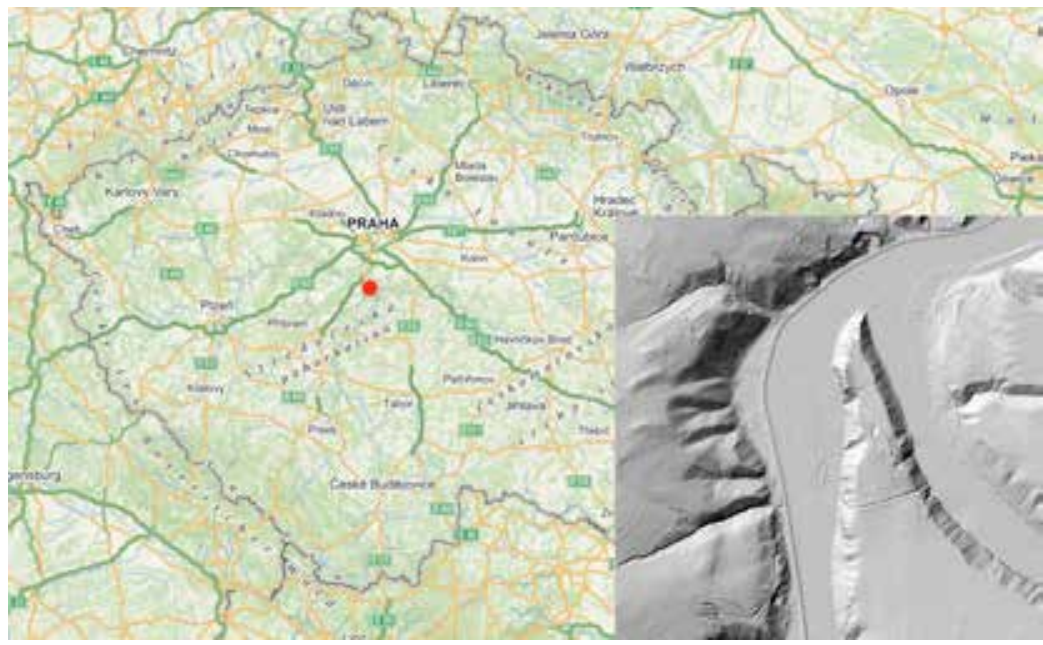

Obr. 1. Poloha lokality s připojeným digitálním modelem terénu lokality a okolí. Zdroj ČÚZK (https://geoportal.cuzk.cz/). Abb. 1. Lage der Fundstelle mit hinzugefügtem digitalen Geländemodell der Fundstelle und der Umgebung. Quelle Tschechisches Amt für Landesvermessung und Kataster (https://geoportal.cuzk.cz/). 
nápadně připomínajících pozůstatky těžebních prací například na hornickém sídlišti v lokalitě Jihlava - Staré Hory (Hrubý 2011). Stěžejními objekty podněcujícími tuto domněnku jsou tzv. zásobnicové jámy zdokumentované v rámci výzkumu východní části lokality svažující se $\mathrm{k}$ řece Sázavě. Středověké sídliště se nachází na skalnatém ostrohu nad soutokem Vltavy a Sázavy (pro zjednodušení bude sídliště v následujícím textu označováno jako Sekanka). Během několikaletého výzkumu byla mimo jiné prozkoumána zejména jeho severovýchodní část $\mathrm{v}$ širším okolí dnes již asanované pískovny, tedy část nacházející se v místech ložiska písku probíhajícího paralelně s tokem Sázavy. Na tomto území bylo postupně zdokumentováno celkem osm tzv. zásobnicových jam - šachet zasahujících několik metrů do pískového ložiska a minimálně ve dvou případech dosahujících skalního podloží. Protože oficiální výzkum lokality započal až v roce 1953, nebyly první nalezené objekty před tímto datem pojaty do souhrnné publikace o výzkumu a jejich číselné označení nesouhlasí s publikovaným číslováním. Předložený text věnovaný představení teorie nové interpretace objektů a jejich chronologických a prostorových souvislostí vychází z informací vybraných hlášení, nálezových zpráv a výsledné publikace o lokalitě (Richter 1982, seznam použitých archivních materiálů uveden na konci textu; obr. 2).

\section{Archeologie}

Dne 5. ř́jina 1950 byl Státním archeologickým ústavem v Praze vyslán na lokalitu spolupracovník JUDr. Václav Patera, aby ověřil nové nálezy učiněné při těžbě písku. V době jeho příchodu bylo ve stěnách pískovny možné spatřit mimo jiné šest zahloubených objektů, z toho dva představovaly úzká vertikální zahloubení. Objekt II. v severozápadní stěně tvořila jáma

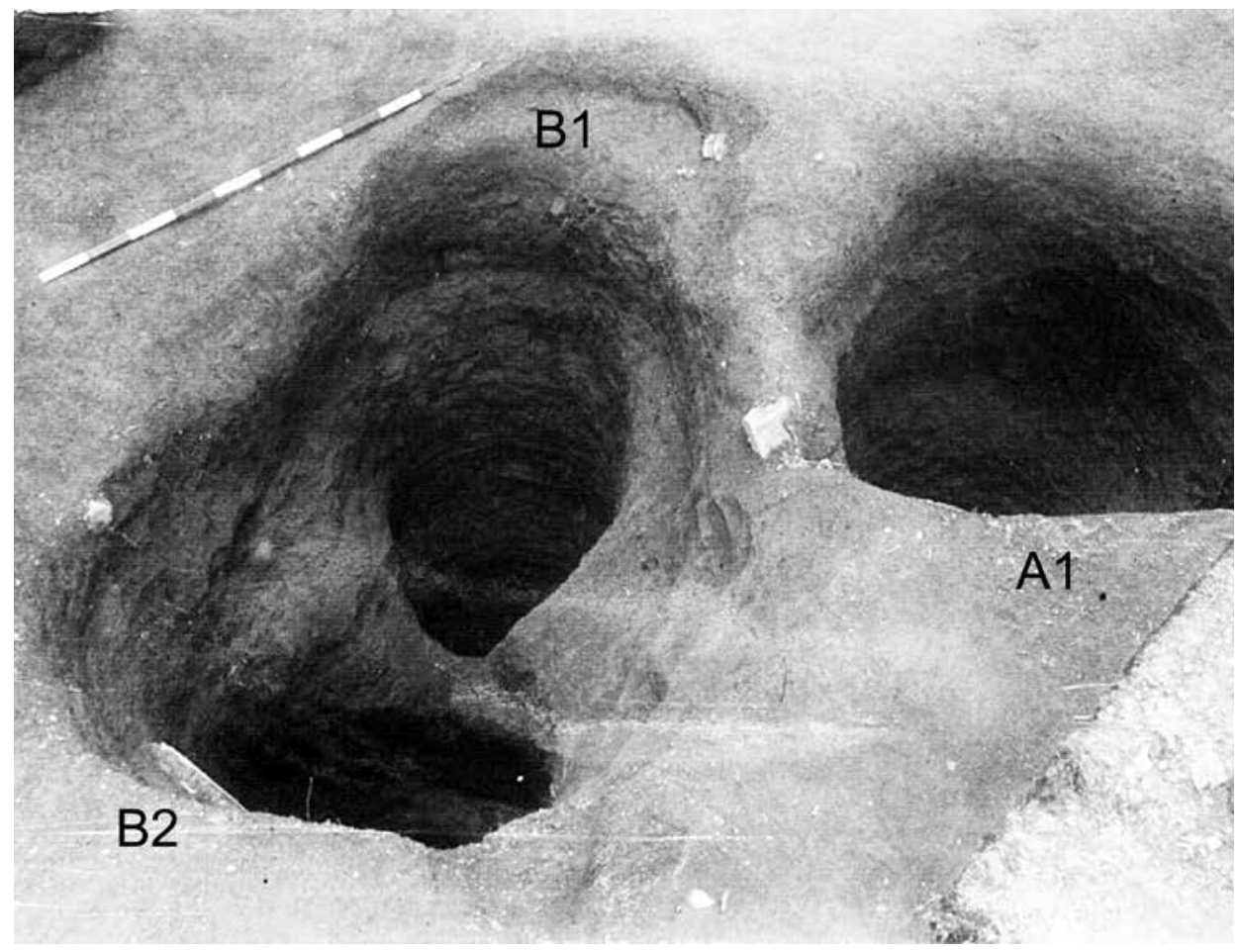

Obr. 2. Pohled od západu na soustavu válcovitých jam v sondě E. Podle NZ 6124/1960, č. neg. 16885.

Abb. 2. Blick von Westen auf das System zylinderförmiger Gruben in Sondierungsgrabung E. Nach NZ 6124/1960, Neg.-Nr. 16885 . 
džbánovitého tvaru hloubky zhruba 4 metrů (průměr ústí $0,5 \mathrm{~m}$ - střed $2 \mathrm{~m}$ - dno $1 \mathrm{~m}$ ). „Komínovitý“ objekt III. v jihozápadní stěně dosahoval hloubky 2 metrů s krátkým šikmým výběžkem (šířky $0,5-0,8 \mathrm{~m}$ ) pokračujícím níže asi $0,25 \mathrm{~m}$. Dlužno poznamenat, že z obou objektů zůstaly zřejmě jen blíže nezkoumané zbytky, vyplněné ve svrchní části šedou hlínou, pod níž byl pouze šedý písek, oba bez nálezů. Dle tvrzení dělníků se v blízkosti druhého objektu nacházel další, bohužel odtěžený, ze kterého měly pocházet keramické nálezy. Při dalších návštěvách již žádné podobné objekty ve stěnách pískovny zjištěny nebyly. Jedinými objekty vybočujícími z řady dokumentovaných pravoúhlých zemnic byly blíže nespecifikované sídlištní objekty v severovýchodní části pískovny. ${ }^{1}$

Další zásobnicové jámy (označení autora výzkumu) zdokumentoval M. Richter až v roce 1957 při sondáži vně pískovny. V sondě E vedené severním směrem byl odkryt objekt sestávající ze tří propojených objektů. Objekt A1 (původně obj. I.) představovala válcovitá jáma hloubky 4,8 metru od povrchu terénu (Ø ústí $2 \mathrm{~m}, \varnothing$ dna $1,4 \mathrm{~m}$ ), vyplněná nejprve pískem promíchaným s hlínou a níže hlinitou vrstvou s pískovými mezivrstvami, pod níž se zvýšil podíl písku a jílu. Vrstvička jílu se nacházela i v horní části kolem stěn. Z objektu pochází bohatý keramický soubor, doplněný bronzovými (přezka) a železnými předměty (hrot střely, přezka, hřebíky, nůž ad.). Objekt B2 (původně obj. II. - A2) tvořil nejlépe zachovaný válcovitý objekt dosahující od povrchu terénu hloubky 5,6 metru (Ø ústí $2,1 \mathrm{~m}, \varnothing$ dna $1,1 \mathrm{~m}$ ). Výplň se téměř shodovala s výplní předchozího objektu, podél stěn se objevovaly šedivé pískové vrstvičky, ve kterých byly ve dvou případech nalezeny železné hřebíky směřující hroty kolmo do podloží. Mimo keramický materiál se zde opět nalezly železné (lopatka, nože) nebo bronzové předměty (kování tvaru lilie). Objekt B1 (původně obj. III.) dosahoval hloubky 4,7 metru od povrchu terénu (Ø ústí strženého erozí $2,6 \mathrm{~m}, \varnothing$ dna $0,7 \mathrm{~m}$ ). Výplň jámy v základních rysech kopírovala předchozí objekty s tím rozdílem, že pod svrchní hlinitopísčitou výplní se nacházela hlinitá vrstvička s uhlíky. Z výplně pochází obdobný keramický materiál, jaký byl nalezen v předchozích objektech. Severovýchodně od objektů byly nalezeny pozůstatky otevřeného ohniště (obr. 3).

Západně od sondy $\mathrm{E}$ byla vedena sonda $\mathrm{F}$ pravděpodobně dokládající terénní planýrky, zjištěné i v zásobnicových objektech. Nejzajímavějším nálezem byla nepravidelně oválná jáma hloubky ca 2 metrů (šířka ústí ca $3 \mathrm{~m}$ ) severně od průměrně 2 metry širokého pásu kamenů. $\mathrm{Z}$ její výplně mimo keramiky shodné s předchozími nálezy pochází bronzové víčko schránky na brakteáty, datované dle P. Radoměrského do první poloviny 13 . století. ${ }^{2} \mathrm{~V}$ okolí sond byly později položeny další zjištovací sondy - např́íklad sonda $\mathrm{K}$ zachytila žlab vedoucí šikmo svahem a ústící do nehluboké jámy, sonda L odkryla dvakrát terasovitě upravený terén s nálezy tuhových tyglíků. ${ }^{3} \mathrm{~V}$ severněji položené sondě 24 byla vybrána tmavá hlinitá výplň, pod kterou se objevila skupina kamenů. V roce 1962 bylo při sondáži severního okolí objeveno několik dalších objektů různého tvaru a účelu, dále nezkoumaných, avšak odlišných od pravidelných půdorysů zahloubených zemnic (NZ 7681/62).

Výzkum posledních dvou původně zásobnicových objektů byl započat v roce 1961. Oproti předchozím objektům byly odkryty v sondě 15 , položené v blízkosti jižního opevnění, asi 100 metrů jižně od okraje pískovny (v prodloužení jižní řady polozemnic). Objekt 15/6 po vybrání veškeré výplně dosáhl hloubky 9,9 metru. Zásadní odlišností této válcovité jámy od jam předchozích bylo dno zatesané do skalního podloží, vystupujícího v hloubce zhruba 8 metrů. Nad ním bylo dochováno dřevěné bednění, vložené do již čtvercového půdorysu jámy. Od hloubky ca 7 metrů začala do objektu prosakovat voda stékající po skalním podloží. Díky tomu byla pravděpodobně původně mělčí zásobnicová jáma prohloubena a upravena na studnu.

Několik metrů severozápadním směrem se mezi zemnicemi 15/1 a 15/2 nacházel objekt 15/7. Jáma válcovitého tvaru byla 4,5 metru hluboká a přibližně 2 metry široká, s hlinitopísčitou

1 Objekty - mísovitou jámu a uhlíkatou vrstvu zachytila při své návštěvě pískovny v roce 1953 Helena Pokorná (Olmerová), objekty ale pouze načrtla (NZ 2908/53), již jen jeden z nich v témže roce orientačně zdokumentoval Josef Kaván (NZ 827/58; Kaván 1956, 384).

2 Radoměrský 1966, v této době však ještě interpretovány jako peněžní oběživo či příslušenství vážek. Nová interpretace například Hrubý a kol. 2006, 244.

3 M. Richter v publikaci klade nález brakteátové ražby do objektu IV. - zemnice, ve zprávě o výzkumu z roku 1957 je jako místo nálezu uveden objekt v sondě F (NZ č. j. 3491/58). 

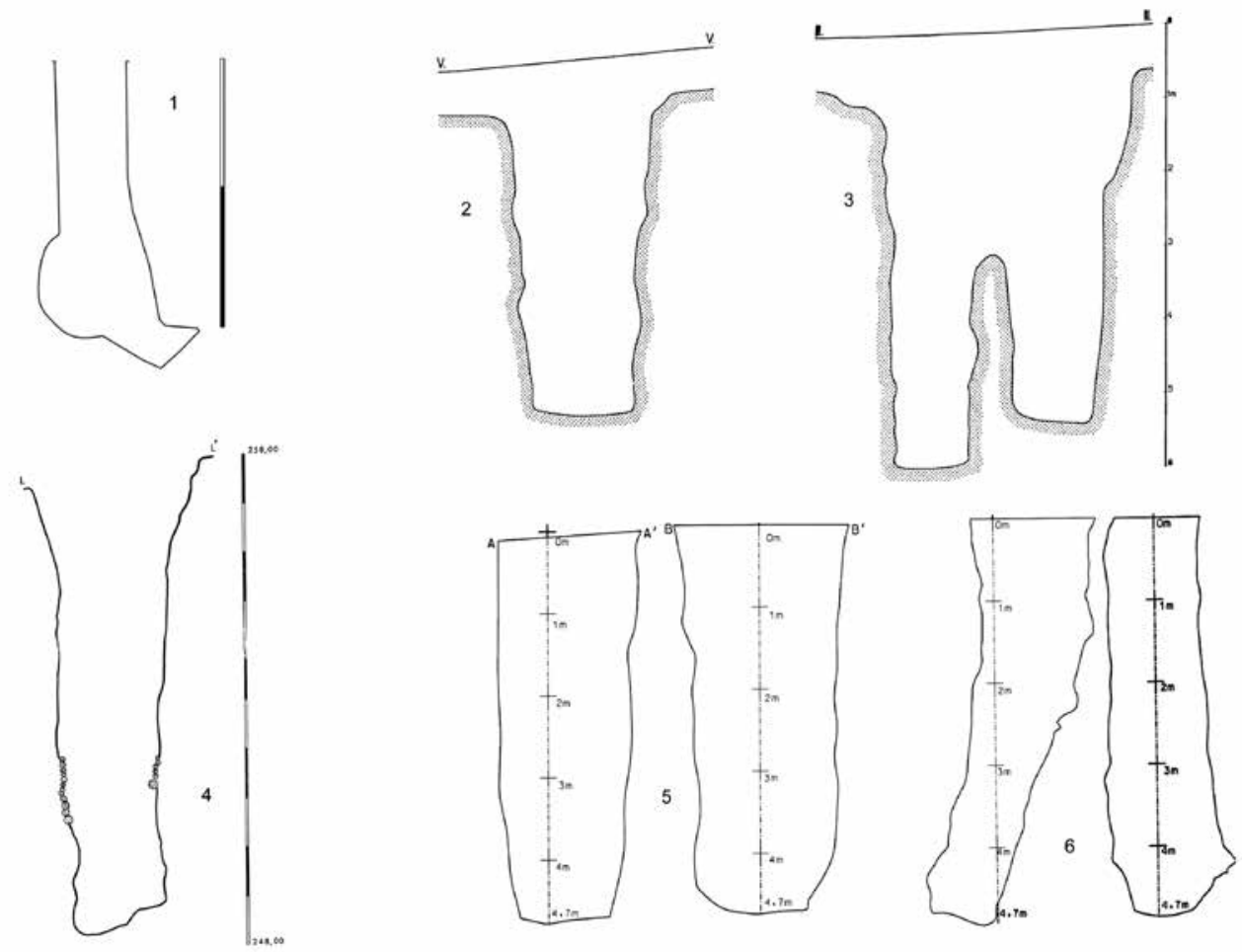

Obr. 3. Řezy „zásobnicových“ jam ze Sekanky a jejich porovnání s průzkumnými šachtami z Jihlavy - Starých Hor. Sekanka: 1 - obj. III/1950, skica; 2 - obj. A1/1957; 3 - obj. B2+B1/1957; 4 - obj. 15/6; Staré Hory: 5 - obj. 2672; 6 - obj. 1634 A. Podle Hrubý 2011, 72, obr. 65.

Abb. 3. Profildarstellung der „Vorratsgruben“ aus Sekanka und ihr Vergleich mit den Schürfschächten aus Jihlava - Staré Hory. Sekanka: 1 - Obj. III/1950, Skizze; 2 - Obj. A1/1957; 3 - Obj. B2+B1/1957; 4 - Obj. 15/6; Staré Hory: 5 - Obj. 2672; 6 - Obj. 1634A. Nach Hrubý 2011, 72, Abb. 65.

výplní téměř bez nálezů. Ve stěnách u dna bylo ve třech směrech odhaleno vertikální pokračování. Severozápadním směrem pokračovala mírně vzhůru ukloněná štola, z počátku jen částečně zaplněná písčitojílovitou vrstvou výšky 1,5 metru a šířky 0,75 metru. Její další pokračování bylo ověřeno sondou vedenou ze dna objektu $15 / 1$ a další severozápadně od tohoto objektu. Zde se již zaplněná štola nacházela v hloubce 1,4 metru a v severním nároží sondy se lomila $\mathrm{k}$ severu. Při jihozápadní stěně sondy se v hloubce 2,7 metru objevilo skalní podloží, pravděpodobně štolou narušené. Její další pokračování je neznámé. Zajímavým jediným nálezem byl pozdně středověký zlomek keramiky. Otvor na východní straně svislé jámy byl pouze 0,5 metru vysoký a sahal do vzdálenosti 1,5 metru. Na východojihovýchodní straně jámy byla pravděpodobně podobná štola, zcela vyplněná pískem s hliněnými mezivrstvami (nebyla zkoumána). Případné další podobné zásobnicové jámy se mohly nacházet v okolí, kde bylo v předchozích letech nalezeno několik dalších objektů, které nebyly po vyloučení jejich příslušnosti k zemnicím dále zkoumány (obr. 4). ${ }^{4}$

4 V sousedství objektu 10/3 byl již v roce 1959 zjištěn objekt, který nebyl pro nedostatek času zkoumán. Pod objektem 10/5 tvoři terén ostře vyhraněnou terasu, ve které se rýsovaly dvě jámy, jedna z nich byla určena jako sídlištní jáma, také však nebyla prozkoumána (NZ 5961/59). 


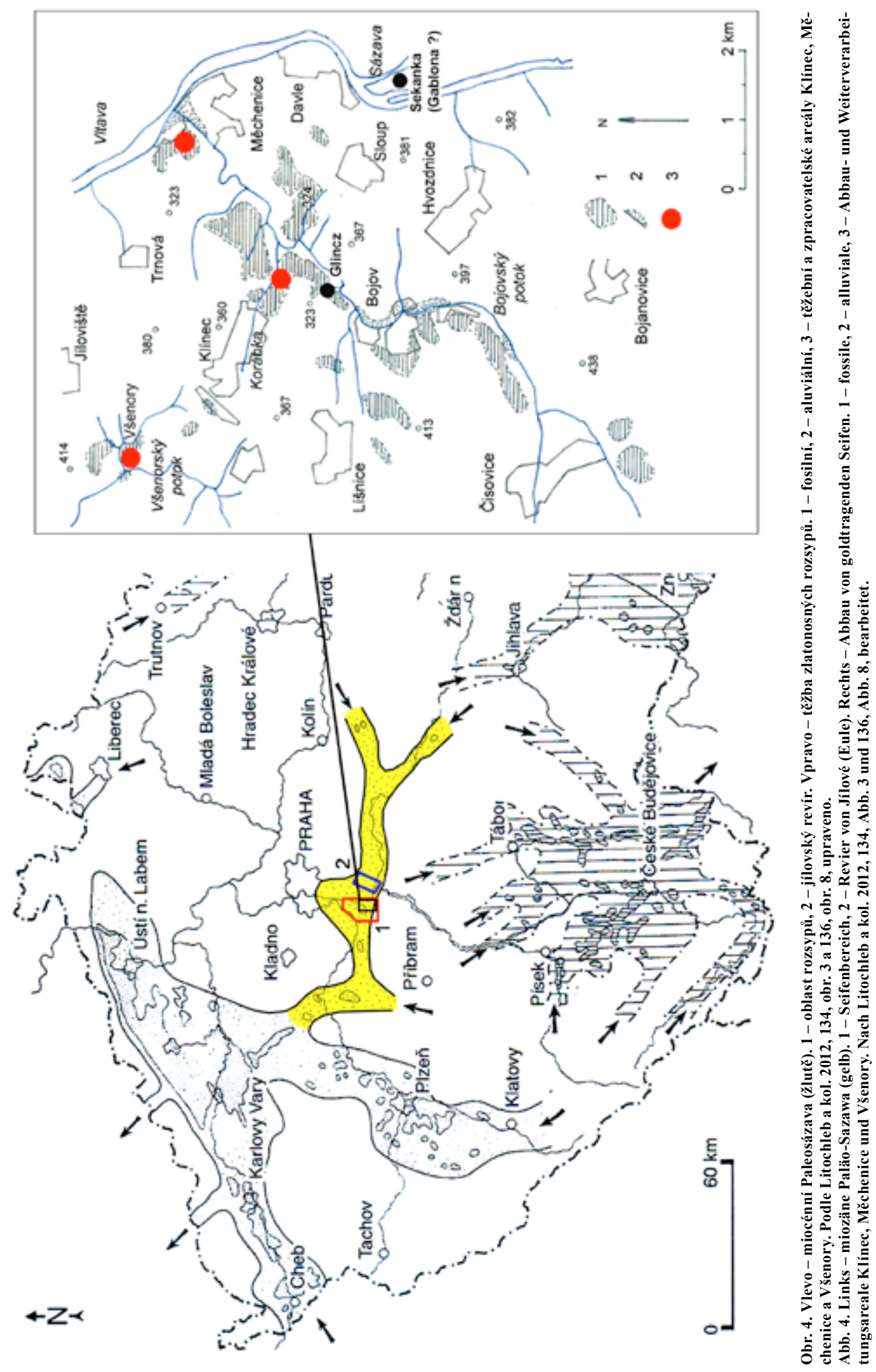




\section{Geologie}

Důležité informace pro teorii o těžebních jamách přináší geologická charakteristika oblasti i lokality samotné. Ostroh s pozůstatky středověkého osídlení se nachází nad soutokem řek Vltavy a Sázavy. Je tvořen skalnatým výběžkem zpevněných sedimentů prachovce a břidlice, který na severním konci prudce spadá k samotnému soutoku. Střední část lokality je však tvořena nezpevněným fluviálním sedimentem, zde představovaným převážně pískem (https://mapy.geology.cz/geocr50/), ve kterém byly situovány všechny popsané zásobnicové jámy. Písek vyplňuje pomyslnou vanu, ohraničenou skalním podložím vybíhajícím ze střední snížené části lokality po východní straně skalního plató směrem k jižnímu opevnění. Podobnou geologickou situaci nalezneme v jihovýchodní blízkosti nedalekého Klínce (lokalita V pekle), který je součástí širší oblasti spojené s dobýváním zlata. Sekanka je situována mezi oblastí miocénních sázavských zlatonosných rozsypů mezi Vltavou a Berounkou a rozsypů nalézajících se západně od jílovského zlatonosného revíru. Na obrázku č. 4 je v detailu vyznačena oblast kolem Klínce s doplněním polohy středověkého hornického městečka na katastru Klínce (Glinz) a možné polohy městečka Jablonná (dle Litochleb a kol. 2012 a Nový 2016). Nejznámější jsou pozůstatky těžby miocénních sázavských hlinitopísčitých a štěrkových (fluviálních) sedimentů - rozsypů převážně v místech teras podél vodních toků, ve dvou prrípadech již i archeologicky zkoumaných, v místech mezi Jílovištěm a Všenory (Kudrnáč 1980) a jižně od Klínce (Richter 1981). V malém množství byly v blíže neurčené době těženy i níže položené rozsypy aluviální, které jsou ještě dnes předmětem zájmu rýžovníků. Pozůstatky povrchové těžby zlata se nachází i na východ od Vltavy na březích Sázavy a na základě shodné geologické situace lze blíže nespecifikovaný výskyt zlatonosných sedimentů předpokládat i přímo na Sekance (obr. 5).

\section{Interpretace}

Jak už bylo v úvodu uvedeno, tento příspěvek si klade za cíl představit novou teorii interpretující zásobnicové jámy, a to jako jámy těžební, související s př́itomností zlatonosných sedimentů. M. Richter považoval částečně prozkoumanou lokalitu za plánovitě systematicky rozvržené homogenní sídliště $\mathrm{s}$ centrálním přibližně obdélníkovitým volným prostranstvím a východní částí na něj navazující (Richter 1963, 208; 1982, 214, 223). Mimo celé řady odchylek právě ve východní části sídliště (dvě zemnice na parcele, vybočení zemnic $11 / 3$ a 27 z předpokládané východní fronty zástavby, přesah zemnic - např. 10/4 - na sousední parcelu apod.) však toto nastíněné rozvržení nepracuje se všemi zjištěnými zahloubenými objekty (obr. 6). ${ }^{5}$ Řemeslnické sídliště ležící v bezprostř̌ední blízkosti ostrovského kláštera mělo být mimo jiné jeho tržním střediskem, některé druhy nálezů také ukazují vazby na těžební okrsky v okolí, konkrétně motyky a špičáky využitelné při povrchové dobývce zlata (naposledy Klápště 2012, 362). Zajímavým nálezem jsou též kladívka - mylně interpretovaná hornická želízka, která můžeme klást do spojitosti s prvními vysloveně hornickými ražbami, jaké z této doby známe z nedalekého Klínce nebo Měchenic (Richter 1982, 171; Litochleb a kol. 2007, 16 a dále). Dosud tak byla lokalita prostřednictvím těchto několika málo zmíněných nálezů spojována pouze $\mathrm{s}$ hornickou činností v okolí. ${ }^{6}$ Předmětem diskuse je dnes i téma zakladatele a vlastníka sídliště na Sekance, kterým nutně nemusel být sousední klášter (naposledy Nový 2016; Vizner-Šmerák 2017). Stejně tak nemáme žádnou informaci o klášterním horním podnikání ve 13. století, ačkoliv na klášterních pozemcích severně od Sloupu jsou zachovány rozsáhlé stopy po těžbě zlata. Klášter pouze získával desátek z kaple nacházející se v nedalekém hornickém městečku Klínec (Tadra 1904, $22-23$ č. 43$)^{7}$

\footnotetext{
5 Do půdorysu nebyla zahrnuta ani chronologicky současná část sídliště v prostoru pískovny, ani sídlištní objekty zjištěné v severním pokračování lokality (objekt 26 a další).

6 Nálezy železného nářadí viz Richter 1982, 167-173. Z. Boháč ve své interpretaci publikovaných výsledků výzkumu přisoudil Sekance funkci hospodářského centra klášterního panství. Na jiných místech však tuto funkci přisuzuje hospodářským dvorům doloženým písemnými prameny (Boháč 1999, 12, 15).

7 První a jediná zmínka o horním podnikání na klášterních pozemcích nedaleko dvora v Libni je datována až k roku 1399 (Boháč 1999, 16).
} 


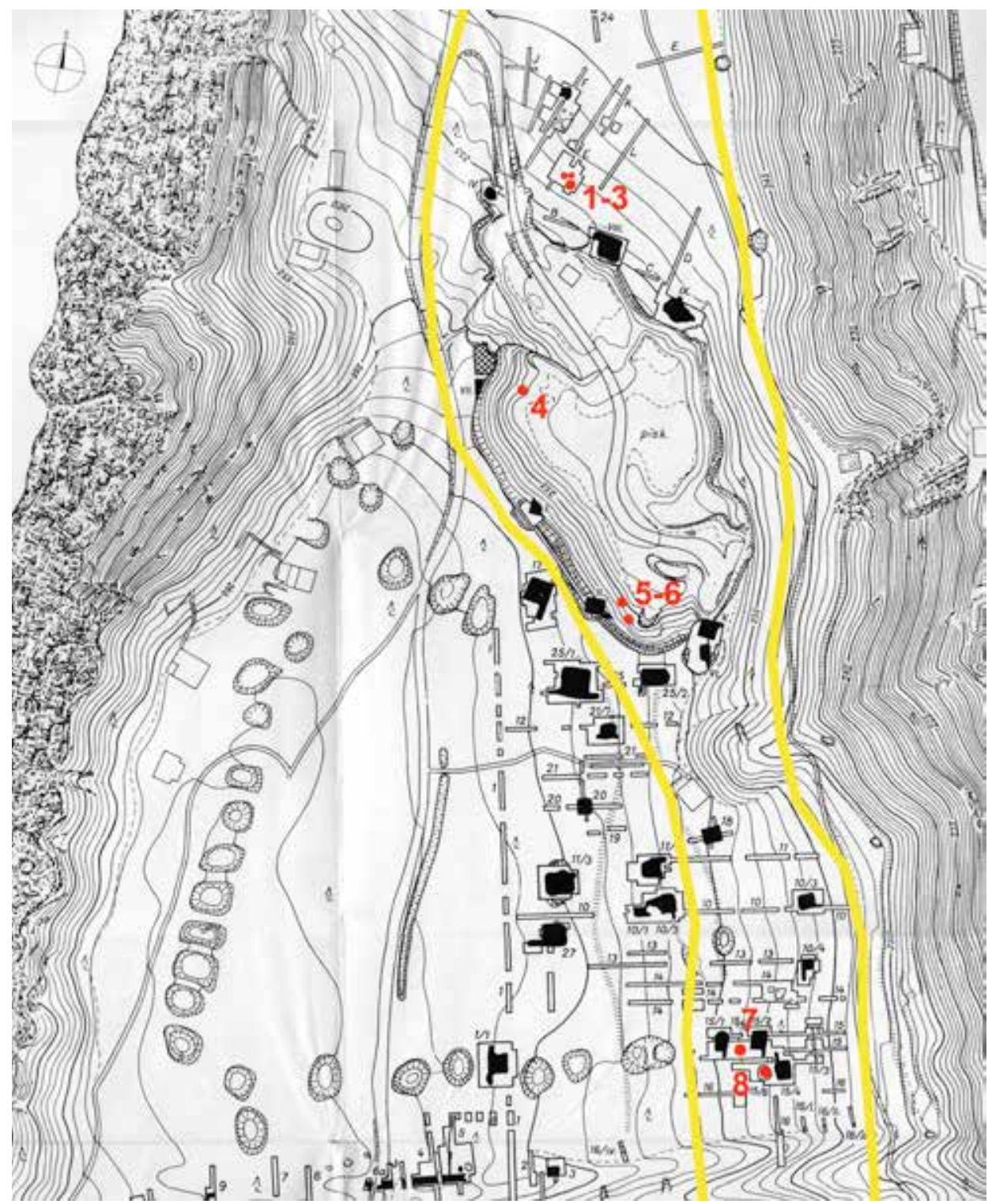

Obr. 5. Plán lokality se zvýrazněnými a doplněnými „zásobnicovými“ jámami. 1-3-obj. A1, B1-2; 4-obj. II/1950; 5-6-obj. III + IIIa/1950; 7 - obj. 15/7; 8 - obj. 15/6; žlutě hranice písčitého podloží. Podle Richter 1982, mapová příloha, upraveno. Abb. 5. Planskizze der Fundstelle mit ergänzten ,Vorratsgruben“. 1-3 - Obj. A1, B1-2; 4 - Obj. II/1950; 5-6 - Obj. III + IIIa/1950; 7 - Obj. 15/7; 8 - Obj. 15/6; gelb Grenze des sandigen Untergrundes. Nach Richter 1982, Kartenanhang, bearbeitet.

Výše popsané zásobnicové jámy lokalizované v prostoru pískové prohlubně obrací pozornost na hornickou aktivitu př́mo $\mathrm{v}$ prostoru samotné lokality. Jejich hloubka se pohybuje od dvou do šesti metrů, pokud budeme předpokládat, že níže zahloubený úsek ve zvodnělém pískovém horizontu a skalním podloží objektu $15 / 6$ byl prohlouben v souvislosti s druhotným využitím jako studny. Jediný takto využitý nalezený objekt zároveň dokládá slabinu vysoko nad řekou 


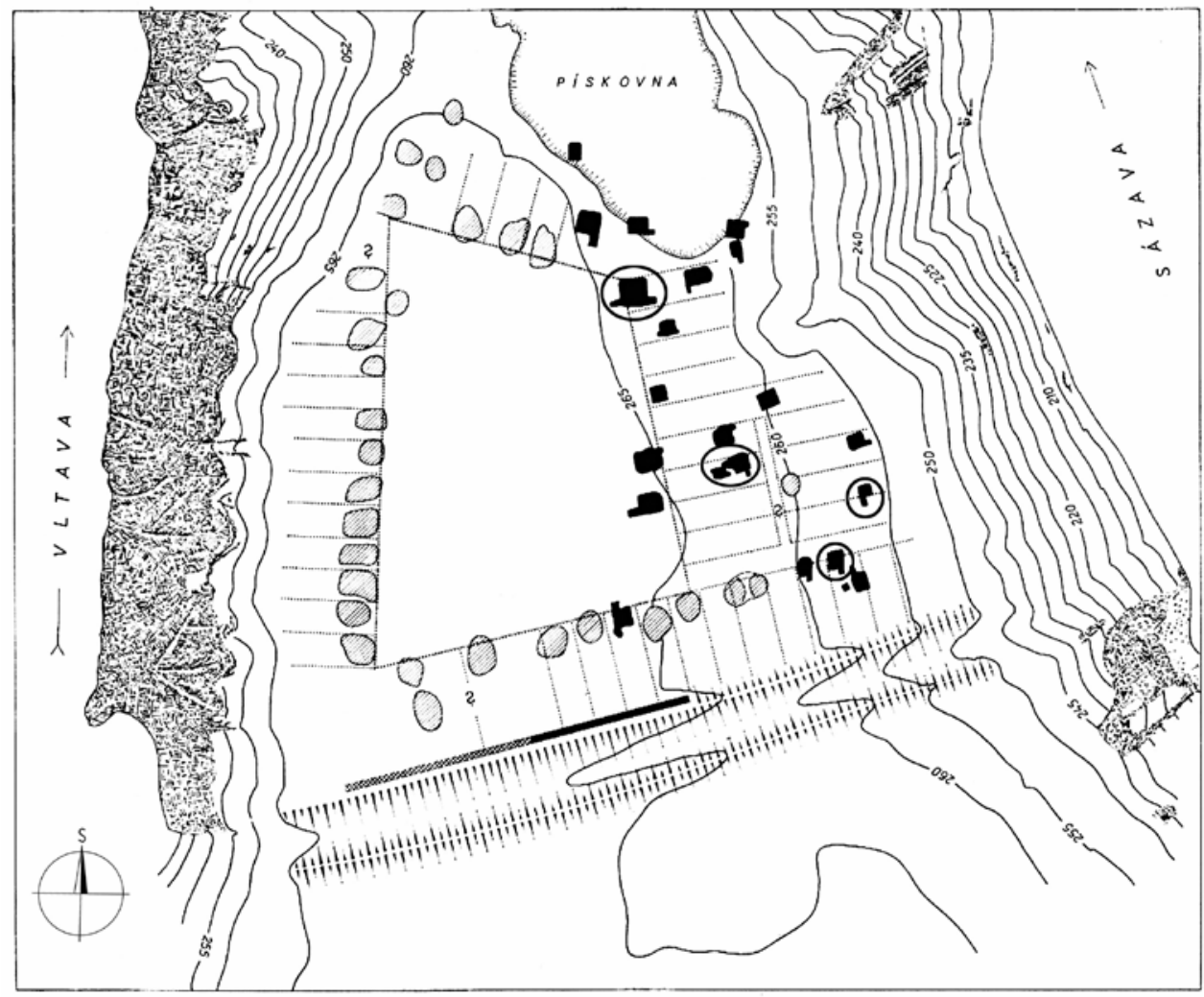

Obr. 6. Předpokládaná parcelace Sekanky s vyznačenými objekty předpokládané starší fáze, s rozvržením nekorespondujícími. Podle Richter 1982, 216, obr. 152.

Abb. 6. Angenommene Parzellierung von Sekanka mit eingezeichneten Objekten der angenommenen älteren Phase, mit nicht korrespondierender Verteilung. Nach Richter 1982, 216, Abb. 152.

založené lokality, v případě vyšší koncentrace obyvatel nutně trpící nedostatkem pitné vody. Interpretaci ostatních šachet jako studní brání zejména jejich menší hloubka nedosahující úrovně spodní vody. Zajímavé horizontální větvení objektu 15/7 naopak teorii o těžebních šachticích, resp. průzkumných štolách, podporuje. Výsledná publikace o lokalitě jej v poznámce k zásobnicovým jámám přiřadila, ale jeho odlišnost blíže nekomentovala (Richter 1982, 52, pozn. 53). Přitom je zejména v tomto př́ípadě jasné, že vertikální rozvětvení jámy nesledovalo zdroj vody. ${ }^{8}$

Stojíme před otázkou týkající se původního účelu těchto jam. Jsou vesměs situovány v pískovém podloží a zahlubují se do něho v různých úrovních svahu i do různých hloubek. První nalezené objekty lze s velkou dávkou jistoty interpretovat jako torza větších a snad i hlubších jam, které byly před příchodem archeologa zničeny těžbou. Např́íklad džbánovitý objekt by nebylo možné vyhloubit skrze jeho úzké hrdlo. M. Richter s poukazem na možné vymazání stěn jílem a pozůstatků dřevěné konstrukce jámy interpretoval jako zásobnice na obilí (Richter 1982, 52). Případné kontaminaci zrna pískem nebo jeho znehodnocení vlhkem tato opatření ale zabránit nemohla. Samo následné vyzvednutí uskladněných obilnin by bylo technicky složité a neobešlo

8 Dlužno poznamenat, že pozdně středověký - v závěrečné publikaci již novověký - zlomek keramiky a nezaplněný prostor štoly navozuje otázku jejího možného sekundárního využití po zániku lokality. Pozdně stř̌edověké zlomky keramiky byly nacházeny v celém prostoru lokality. Podobně staré nálezy pochází z těžební oblasti v okolí Klínce, pravděpodobně odrážejí pokusy o obnovení těžby zlata (ústní sdělení J. Vizner - T. Palatý). 
by se beze ztrát. Za zásobní jámy jsou jinak pokládány prostorné jámy zahloubené př́ímo $\mathrm{v}$ interiérech některých objektů, jedná se však spíše o ojedinělý jev (Richter 1982, 44). Jakkoliv sít' sond zdokumentovala množství větších či menších sídlištních objektů, nebyly v prozkoumané části sídliště zjištěny ani obvyklé doprovodné sanitární objekty, zpravidla zastoupené nejrůznějšími druhy jímek.

Po zvážení výše uvedeného se domnívám, že představené zásobnicové jámy nebyly výsledkem záměrně vykopaného prostoru ke skladování, ale jedná se o pozůstatky prospektorských šachet pátrajících po zlatonosných sedimentech. Rozdílné hloubky mohou odrážet konkrétní prospektorské zájmy, u mělčích jam ale nelze př́ípadně vyloučit možnost nerozpoznání jejich pokračování skrze výplň identickou s okolním podložím. ${ }^{9}$ Naopak šachty v jihovýchodní části sídliště měly pravděpodobně za cíl dosažení úrovně pevného skalního podloží. Jiné využití nebo vysvětlení těchto hlubokých jam se zatím nenabízí. Jejich spojení například s těžbou písku není ani logické, ani bezpečné. Je možné, že pozůstatky těžby pravděpodobně přivedly obyvatelstvo okolních obcí k ložisku písku, jehož těžba nabrala na obrátkách v první polovině 20. století. ${ }^{10}$ Specifické zahloubení jam do pískového prostředí bez spojitosti s existencí zlatonosných sedimentů na straně jedné dlouho znesnadňovalo interpretaci prospekčních šachet, na straně druhé nedává mnoho prostoru pro širší srovnání s dalšími podobnými montánními aktivitami. V širším okolí takováto prospekce zatím bud' nebyla nalezena, nebo nebyla vzhledem k charakteru a hloubce těženého zlatonosného sedimentu potřebná. Jihovýchodně od Klínce v lokalitě $\mathrm{V}$ peklech se nachází podobná geologická situace, kde byl dnes již vytěžený zlatonosný sediment zakryt několik metrů mocným pokryvem sprašových hlín. Jeho odhalení mohlo být provedeno právě pomocí obdobných šachtic. ${ }^{11}$ Nálezy ze Sekanky tak lze zatím orientačně srovnávat s šachticemi z hornických sídlišt' souvisejících s klasickou hlubinnou těžbou, a to jen ve výjimečných případech. Jedním z nich je právě sídliště v Jihlavě, kde byly podobné jámy prozkoumány. Zajímavá je i zdejší odlišnost těchto prospekčních (průzkumných) či slepých jam, které nedosáhly $\mathrm{k}$ hledanému rudnému ložisku a byly později přírodním i umělým způsobem vytěženým materiálem zpětně zaplněny (Hrubý a kol. 2006, 190). Obdobnou situaci nalezneme na Sekance, zejména u tří objektů v sondě E, doklady umělého zasypání objektů a planýrování terénu lze ale ve zprávách nalézt i pro jejich širší okolí. ${ }^{12}$ Vysvětlovalo by to též absenci charakteristických terénních depresí a elevací, které jsou jinak typickými pozůstatky po povrchové těžbě zlata v okolí. Tuto činnost lze klást do souvislosti s likvidací reliktů staršího osídlení nebo jen se změnou využití této části sídliště (např. Richter 1982, 24, 51). Na obrázku č. 5 je demonstrován rozdíl mezi uměle zaplněnou (téměř) celou jámou - šachtou ze Sekanky nebo zřejmě větrací šachtou podzemní štoly v Kašperských Horách a přirozeným způsobem postupně zaplněnou šachtou v Jihlavě - Starých Horách (obr. 7). ${ }^{13}$ Za současného stavu poznání není možné určit skutečný rozsah prospektorských prací, stejně tak možné následné těžby sedimentu. Finální získávání zlata z těženého materiálu nemohlo probíhat bez zdroje vody, z čehož lze usuzovat na související areál na břehu jedné z řek. Pozůstatky po zpracování surového zlata ze Sekanky neznáme. ${ }^{14} \mathrm{~S}$ teorií předpokládaného těžebního areálu nutně souvisí otázka jeho datování. Zde

\footnotetext{
9 Je nutné si uvědomit primitivní a nebezpečný způsob vybírání těchto jam, jak ostatně potvrzuje i jeden z návštěvníků výzkumu a autor př́iběhu Anály dlouhé půl života Z. Smetánka $(1992,62)$.

10 Dle fotografie lokality z počátku 20. století lze v místech pískovny sledovat rozsáhlý plochý terénní zářez se zřetelnou odtěženou stěnou (Vizner-Šmerák 2017, foto obálky infosešitu). Kvůli dnešnímu sanovanému terénu bývalé pískovny a okolí není zatím možné posoudit, zdali zde není zachycena již ve středověku odtěžená část terénu.

11 Na rozdíl od Sekanky byly i v této lokalitě zlatonosné sedimenty vytěženy. Recentní propady však dokládají dobývání zlatonosného horizontu při skalním podkladu pomocí šachtic a štol mezi Bojovem a Klíncem (Litochleb a kol. 2012, 137).

12 Objekt B1 - „Zdá se, že po vytvoření nejspodnějši vrstvy, či před koncem tohoto procesu - pravděpodobně přirodního, bylo krátce jam užito jako odpadních a následujíci vrstvy jsou již dílem záměrného planýrování prostoru, jak se s ním setkáváme též u jiných - snad obytných $i$ výrobnich - objektů. Pokud tento závěr by měl konečnou platnost, musel by ovšem predpokládat, že úprava terénu - ne dlouho po opuštění objektů - měla sloužit nějakému dalšimu osidleni.“ (NZ 6124/60). „Do objektu zasypaného až na úroveň okolniho terénu byl v jihovýchodním nároži zahlouben jiný objekt (...)“( Richter 1982, 30).

13 Mimo jihlavských nálezů neznáme podobné zahloubené objekty, šachta z Kašperských Hor odpovídá pouze svým charakterem a je využita pouze pro demonstraci výplně planýrovaného objektu v sídlištním prostředí (Kašák 2010,111). M. Richter předpokládá další vyrovnávání terénu v souvislosti s přeměnou prostoru sídliště na pole (NZ 243/58,14).

14 Existence zářezu v místech pískovny (viz pozn. 10), erozní rýha jižně od pískovny i zaniklá cesta ústící na sázavský břeh pod pískovnou naznačuji případnou polohu zpracovatelského areálu v těchto místech.
} 


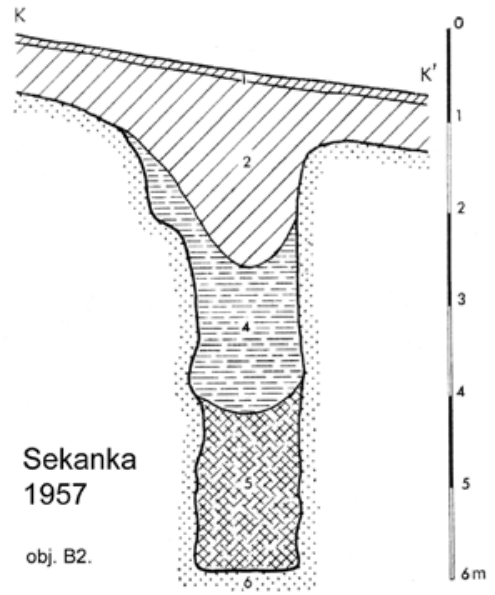

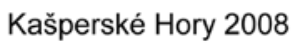

sonda č. 4

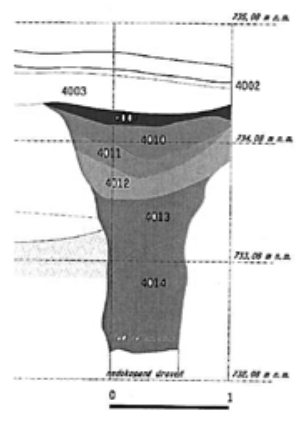

Jihlava - Staré Hory 2002

obj. 0634

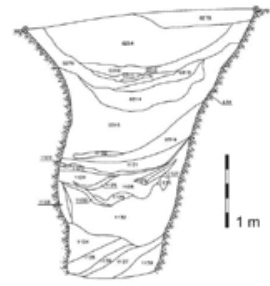

Obr. 7. Porovnání uměle vzniklé výplně objektu B2 ze Sekanky (Richter 1982, 51, obr. 28) a vertikální šachty z Kašperských Hor (Kašák 2010, 111, obr. 37) s postupně narůstající výplní šachtic v Jihlavě - Starých Horách (Hrubý a kol. 2006, 192, obr. 21).

Abb. 7. Vergleich zwischen künstlich entstandener Verfüllung von Objekt B2 aus Sekanka (Richter 1982, 51, Abb. 28) und den vertikalen Schächten aus Kašperské Hory (Kašák 2010, 111, Abb. 37) mit schrittweise zunehmender Verfüllung der Schachtes in Jihlava - Staré Hory (Hrubý a kol. 2006, 192, Abb. 21).

je však možné se již přidržet výsledků archeologického výzkumu. Mimo nejhlubší šachty, jíž mladší úprava na studnu zajistila existenci minimálně i na celou dobu mladšího lokačního městečka, lze tuto hornickou fázi datovat do období před a kolem poloviny 13 . století. ${ }^{15}$ Tato datace bude mít významnou roli v diskusi týkající se počátků a největšího rozmachu těžby zlata v této oblasti, dosud kladené na základě písemných pramenů spíše do 14. století (Žemlička 1974, 440).

Popsané prospekční jámy ovšem neexistovaly samy o sobě. Dle výzkumů hornických osad se nacházela bud' v těsné či blízké vzdálenosti obytná stavení (Derner-Hrubý 2018). V př́ípadě Sekanky je nepravděpodobné, aby se související hornické příbytky nacházely mimo areál př́írodně vyčleněné lokality. Naopak lze sledovat, že jednotlivé šachty se nachází v místech vzdálených do zhruba 10 metrů od nejbližšś zemnice. ${ }^{16}$ Jejich vzájemnému propojení chybí důkladnější rozbor nálezů, existují však indicie, že by tomuto mohly nasvědčovat společné chronologické znaky. Především je zde podobnost, co se týče úmyslného zasypání či zplanýrování některých obytných a sídlištních objektů, jejichž prostor byl upraven pro jiné využití (Richter 1982, 24, 55; obr. 8). Ve skupině prozkoumaných zemnic se nachází i velká část takových, které přímo vykazují dvě stavební/chronologické fáze. Tento jev dosud nebyl odborně posouzen. M. Richter existenci dvou časových horizontů představil, ale o její vysvětlení se kvůli nedostatku podobných nálezů nepokusil. Ve srovnávací studii věnované vrcholně středověkým zemnicím tento jev nebyl zahrnut (Vařeka 2002). Sekanka je ze zde posuzovaných lokalit totiž jediná, na které byl dosud zdokumentován. Jedním z výsledků studie je předpoklad, že zemnice představuje první stavbu (součást stavby) lokovaného městského sídliště, která je v horizontu několika let nahrazena stavbou kamennou v průčelí parcely. ${ }^{17}$ Proto je třeba si klást otázku, proč zde nedošlo k následné kamenné výstavbě a je zde naopak zachycena přestavba zemnic. Přesnou dobu života těchto staveb z mnoha důvodů nedokážeme určit, ve zmíněném Vařekově článku bylo

15 Stále platná datace klade počátky života Sekanky na sklonek 2. čtvrtiny 13. století (Richter 1982, 238).

$16 \mathrm{~V}$ textu bude i nadále pracovně použiván pojem zemnice, ačkoliv se se vší pravděpodobností jednalo o součást nadzemní stavby (Vařeka 2002; Vizner-Šmerák 2017, 24-26).

$17 \mathrm{~V}$ tomto př́spěvku není důležitý charakter stavby, jaký zemnice představuje, jakákoliv přestavba zahloubené stavby se neobešla bez přestavby př́ipadných ostatních částí. 


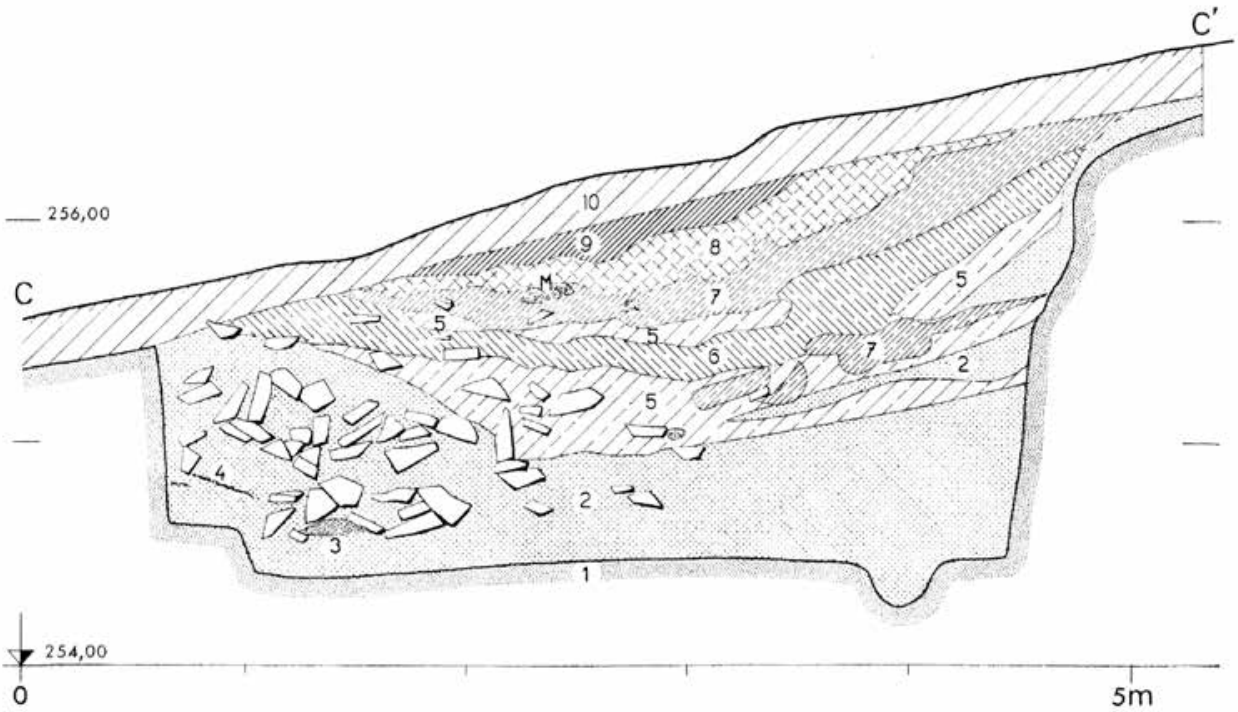

Obr. 8. Řez objektem 10/4, na jehož výplni lze demonstrovat záměrné planýrování zemnic. Vyplnění objektu závalem z písku a kamení - vrstva 2. Podle Richter 1982, 25, obr. 12.

Abb. 8. Profildarstellung von Objekt 10/4, an dessen Verfüllung man eine absichtliche Planierung der Grubenhäuser demonstrieren kann. Verfüllung des Objektes durch Einsturzmasse aus Sand und Steinen - Schicht 2. Nach Richter 1982, 25, Abb. 12.

poukázáno na velké rozdíly v délce používání zemnic, které mohly a nemusely být způsobeny jejich životností. Přesnější chronologický údaj poskytuje výzkum ve Žd’áru nad Sázavou, kde lze díky písemnému pramenu odhadnout dobu sídliště na zhruba 15 let, přičemž po této době došlo bez známek dokládajících případnou stavební úpravu k jeho přeložení do nové polohy (Zatloukal 1999). Díky této informaci je žd’árská lokalita velmi zajímavá. Většinou je však archeologickým výzkumem zdokumentována časová souslednost nebo i současnost s kamennou stavbou. Důležité je také zjištění, že je možné pozorovat chronologicky podchycenou změnu půdorysu, kterou lze u zemnic dokumentovat jako postupné zmenšování půdorysu a přechodu čtvercového $\mathrm{k}$ obdélníkovému půdorysu. Toto pozorování lze v několika př́ípadech potvrdit i na Sekance, kde však k těmto změnám dochází právě v rámci přestavby objektů (obr. 9). Mladší fáze objektů často představují zmenšené obdélníkové půdorysy zemnic se změněnou orientací vstupní šíje. Při snaze o vysvětlení těchto anomálií se nabízí řešení nepřímo již vyřčené. Objekty dokládající dvě stavební fáze nepředstavují stavební úpravy v počátcích městské lokace, ale stavby dvou různých sídlišt', z nichž pouze mladší odpovídá prezentovanému pravidelnému městskému založení. Starší sídliště bylo představováno nepravidelnou pásovou zástavbou, těžebními šachtami a dalšími technickými a hospodářskými objekty hornického sídliště souvisejícího s prospektorskou činností zaměřenou na zlatonosné sedimenty v prostoru Sekanky a pravděpodobně i jejím okolí. ${ }^{18}$ Charakter sídliště odpovídá spíše hornickým osadám, jejichž zástavba nevykazuje pravidelné uspořádání. Zajímavá je také podobnost sídliště s jinými hornickými lokalitami v některých bodech infrastruktury - na Sekance např́íklad chybí prokazatelné doklady hospodářských staveb nebo sanitárních objektů (odpadní jámy, jímky a pravděpodobně i studna, jejíž existenci předpokládáme až pro mladší sídliště - Derner-Hrubý 2018, 219, 222). Finální podobu sídliště

18 S přítomností horníků je možné snáze vysvětlit vznik tak náročné stavby, jako je do skály vytesaná př́istupová cesta. Mimo dodnes existující cesty k Vltavě existovala pravděpodobně i cesta k Sázavě (Richter 1982, 218). Je také možné uvažovat o souvislosti osady s pozůstatky montánní činnosti na sousedních svazích údolí Vltavy i Sázavy. 


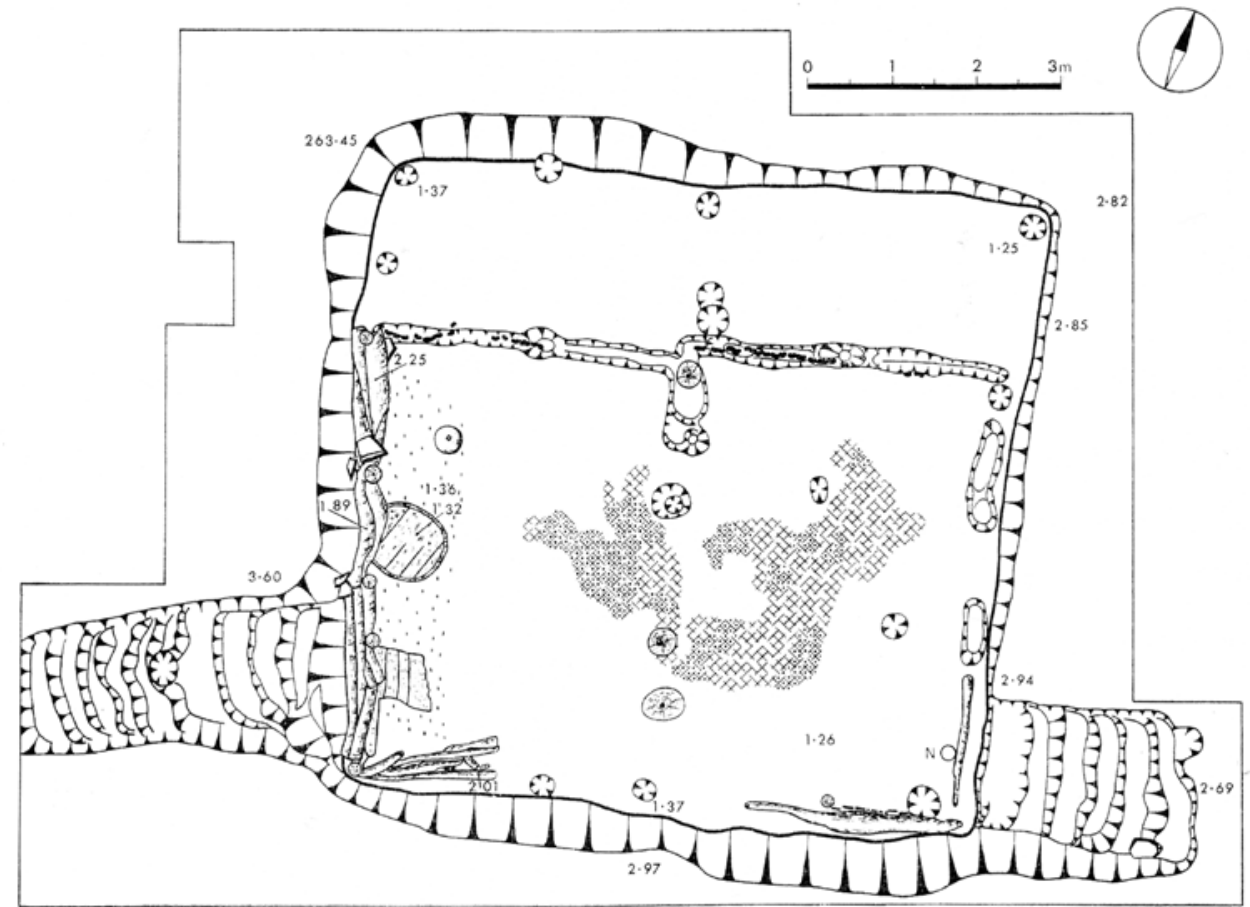

Obr. 9. Půdorys objektu 25/1 představujíí ideální chronologický př́íklad proměny chronologicky starší čtvercové zemnice na mladší a menší obdélníkovou zemnici s opačně orientovaným vchodem. Podle Richter 1982, 35, obr. 23.

Abb. 9. Grundriss von Objekt 25/1, der ein ideales chronologisches Beispiel für den Wandel der älteren quadratischen Grubenhäuser zu kleineren rechteckigen Grubenhäusern mit umgekehrter Eingangsorientierung darstellt. Nach Richter 1982, 35, Abb. 23.

na Sekance zatím není možné s určitostí rekonstruovat, nebot' je zde celá řada objektů, které bez detailní revize nálezového materiálu nemůžeme s určitostí přiřknout konkrétní fázi osídlení celé lokality. Již ted' se rýsuje varianta, že staršímu sídlišti bude pravděpodobně možné přisoudit i ty zemnice, v jejichž výplni nebyly zachyceny stopy požáru, nebo požárové vrstvy vznikly až $\mathrm{v}$ částečně zaplněném objektu (obr. 10). ${ }^{19}$

\section{Závěr}

V rámci studia hlášení a nálezových zpráv ze záchranného archeologického výzkumu středověké řemeslnické osady Sekanka nad soutokem Vltavy se Sázavou byla nově interpretována skupina zahloubených objektů - zásobnicových jam. Jejich podobnost s hornickými těžebními šachtami podtrhuje situování v písečných sedimentech, kde lze jen stěží hledat jiný význam nebezpečně zahloubených objekti̊. Předložený text zároveň přináší nový pohled na strukturu a charakter zástavby známé středověké lokality. Od okamžiku publikování výzkumu nebylo dále pracováno se zajímavým a v podstatě výjimečným zjištěním dvou stavebních fází zemnic, spojených s umělým planýrováním terénu staršího sídlištního horizontu. Na základě výše uvedeného textu byla tato situace interpretována jako časová následnost starší hornické osady související s prospekční činností zaměřenou na zlatonosné sedimenty a mladší řemeslnické osady,

19 Např́iklad objekt 10/3. Požárové vrstvy jsou považovány za doklad násilného zániku městečka vpádem Braniborů. Do rozlohy sídliště zatím nebyly zahrnuty sídlištní objekty nacházející se severně od pískovny. 


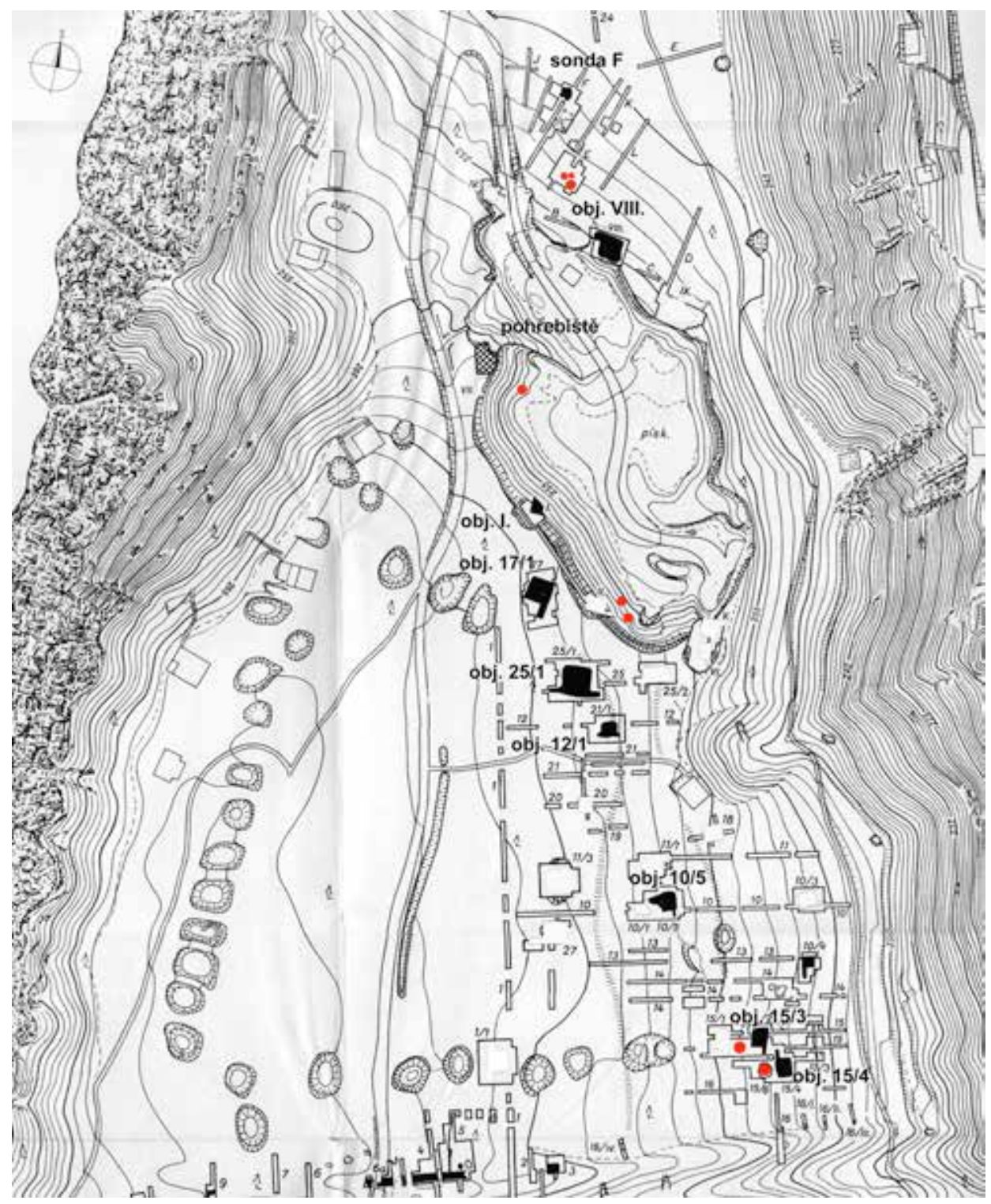

Obr. 10. Půdorysný plán lokality představující předpokládanou starší fázi sídliště. Podle Richter 1982, mapová př́íloha. Abb. 10. Grundrissplan der Fundstelle, der die angenommene ältere Siedlungsphase darstellt. Nach Richter 1982, Kartenanhang.

pravděpodobně poměrně záhy zničené během braniborských válek. Tímto modelem lze nejen vysvětlit půdorysné rozvržení sídlištních objektů, interpretovat specifické zahloubené objekty, ale snad i objasnit zajímavou absenci následných kamenných staveb, které by bylo možné u lokality trvající minimálně od poloviny 13 . století do konce 70 . let téhož století očekávat. Z pohledu aktivit spojených s těžbou zlata přináší cenné informace nejen o charakteru prospekčních prací, který nebyl v této oblasti dosud doložen, ale i o jejich datování. Dosud pouze nepř́mé informace, 
získané například prostřednictvím archeologického výzkumu hornického sídliště a na něj volně navazujícího výzkumu geologického u nedalekého Klínce, naznačovaly v této oblasti možnost těžby zlata nejdříve ve druhé polovině 13. století. Předložený text mimo zjištění hornické minulosti lokality poukazuje na množství nezpracovaných informací týkajících se jak terénních situací, tak i archeologických nálezů, které tato výjimečná lokalita stále nabízí a které by bylo př́nosné zpracovat.

\section{Nálezové zprávy uložené v archivu ARÚ AV ČR, Praha, v. v. i.}

KAVÁN, J.: č. j. 827/58, 827/58A, 827/58B.

PATERA, V.: č. j. 5893/50.

POKORNÁ, H.: č. j. 2908/53.

RICHTER, M.: č. j. 3646/57, 3912/57, 243/58, 3491/58, 3572/58, 4517/58, 3080/59, 5961/59, 5578/60, 6124/60, 6124/60A, 3952/61, 6396/61, 2941/62, 3244/62, 3899/62, 4007/62, 5221/62, 5522/62, 6028/62, 6370/62, $7211 / 62,7681 / 62,5330 / 63,7277 / 63$.

\section{Literatura}

DERNER, K.-HRUBÝ, P., 2018: Otázka zemědělství a potravinářské produkce středověkých hornických komunit - Zur Frage der Landwirtschaft und Nahrungsmittelproduktion mittelalterlichen Bergbaukommunitäten, AH 43, 213-245.

HRUBÝ, P., 2011: Jihlava - Staré Hory. Archeologický výzkum středověkého důlního, úpravnického a obytného areálu v letech 2002-2006. Př́́spěvek ke studiu středověkého rudného hornictví. Praha - Brno.

HRUBÝ, P. a kol., 2006: Hrubý, P.-Jaroš, Z.-Kočár, P.-Malý, K.-Mihályiová, J.-Militký, J.-Zimola, D., Středověká hornická aglomerace na Starých Horách u Jihlavy, PA XCVII, 171-264.

KAŠÁK, K., 2010: Hlubinné dobývání zlata v Kašperských Horách. Diplomová práce, ulož. na FF ZUČ, vedoucí práce doc. Mgr. Karel Nováček, Ph.D. Dostupné z: https://theses.cz/id/s7ct71/, cit. 5. 1. 2019.

KAVÁN, J., 1956: Archeologický výzkum v Hradišt'ku u Davle, AR VIII, 377-386.

KLÁPŠTĚ, J., 2012: Proměna českých zemí ve středověku. Praha.

KUDRNÁČ, J., 1980: Svědectví archeologie o těžbě zlata v Čechách, Rozpravy Národního technického muzea v Praze 78. Studie z dějin hornictví 12, 7-24.

LITOCHLEB, J. a kol., 2007: Litochleb, J.-Sejkora, J.-Palatý, T.-Šimon, T., Těžba zlatonosných rozsypů v jižním okolí Prahy. In: Stříbrná Jihlava 2007. Studie k dějinám hornictví a důlních prací. Příspěvky z konference Stř́ibrná Jihlava 4.-7. 10. 2007, 10 -25. Jihlava.

LITOCHLEB, J. a kol., 2012: Litochleb, J.-Černý, P.-Sejkora, J.-Šrejnová, B.-Korba, M., Ložiska a výskyty nerostných surovin na území brdských Hřebenů a v jejich okolí (střední Čechy), Bulletin mineralogicko-petrologického oddělení Národního muzea v Praze 20, č. 2, 129-176.

NOVÝ, P., 2016: Opidum Gablona. Příspěvek k lokalizaci zaniklého městečka z listin zbraslavského kláštera, HG 42, č. 2, 169-180.

RADOMĚRSKÝ, P., 1966: Př́íspěvek k datování středověké osady na Sekance a problematika nálezů tzv. měděných brakteátů ve střední Evropě, MVP IV, 151-157.

RICHTER, M., 1963: Výzkum opevněné středověké osady v Hradišt'ku u Davle, AR XV, 200-219, 221-223.

- 1981: Zaniklá hornická osada u Klínce, Praehistorica VIII, Varia archaeologica 2, 301-306.

- 1982: Hradišt'ko u Davle - městečko ostrovského kláštera. Praha.

SMETÁNKA, Z., 1992: Hledání zmizelého věku. Praha.

TADRA, F., 1904: Listy kláštera zbraslavského. Praha.

VAŘEKA, P., 2002: Zahloubené stavby v českých městech vrcholného středověku - zemnice nebo suterény nenalezených nadzemních domů? In: Archeologie nenalézaného. Sborník přátel, kolegů a žáků k životnímu jubileu Slavomila Vencla, 252-285. Dobrá Voda u Pelhřimova.

VIZNER, J.-ŠMERÁK, V., 2017: Sekanka. Pompeje nad soutokem Vltavy a Sázavy. Krňany - Jílové.

ZATLOUKAL, R., 1999: Zpráva o archeologickém výzkumu ve Žd’áře na Sázavou, trat' Staré město, v letech 1996-1999, Mediaevalia archaeologica 1, 193-207.

ŽEMLIČKA, J., 1974: Osídlení Zbraslavska od 10. do počátku 15. století, PA LXV, s. 419-465. 


\section{Zusammenfassung}

\section{Überreste einer mit der Prospektion von Goldlagerstätten an Orten einer mittelalterlichen Dorfwüstung verbundenen Montantätigkeit}

Bei einer Überprüfung der genauen chronologischen Abgrenzung des Lebens der archäologisch untersuchten sich am Zusammenfluss der Moldau und Sazawa in der Nähe von Davle (Richter 1982) befindenden mittelalterlichen Fundstelle Sekanka wurden beim Studium von Archivnachrichten und Fundberichten Informationen entdeckt, die dem gegenwärtig angenommenen Bild der dortigen Stadtgründung nicht entsprechen. Zur Grundlage für die präsentierte Theorie von einer komplizierteren Raumstruktur, und damit auch von den Anfängen der Stadtlokation, wurden sog. Vorratsgruben. Die spezielle Form und Einzigartigkeit des Vorkommens war bis dato kein Gegenstand eines Versuches ihrer Neuinterpretation. Unter dem Einfluss aktueller Grabungen in Bergbausiedlungen und in den daran angrenzenden Abbau- und Weiterverarbeitungsarealen (z. B. Hrubý 2011) können diese tiefen zylinderförmigen Gruben mit Prospektionsschächten in Verbindung gebracht werden, die in dem sandigen Teil des Untergrunds der Fundstelle goldtragende Sedimente beobachten (die untersuchte Fundstelle befindet sich in einem Gebiet mit reichhaltigen Belegen fúr mittelalterlichen Goldabbau). Mit den Funden der Abbaugruben können auch einige weitere entdeckte Siedlungsobjekte in der Umgebung in Verbindung gebracht werden, einschließlich Wohnbauten, deren Überreste Grubenhausobjekte darstellen. Außer vergleichbaren Belegen für absichtliche Planierschichten können der Bergbausiedlung auch Grubenhäuser zugeordnet werden, bei denen einzelne Umbauten dokumentiert wurden, die in der Chronologie ihrer Entwicklung jüngere und ,modernere“ Elemente darstellen - große quadratische Grubenhäuser wandeln sich dort zu kleineren rechteckigen Grubenhäusern (Vařeka 2002). Diese Feststellungen werfen ein neues Licht auf die Datierung und Dauer der frühen Stadtlokation, deren Anfänge sich somit nicht mit dem Beginn der Besiedelung der Fundstelle decken, sondern erst später kommen, nachdem das Leben der Bergbausiedlung auf natürliche oder künstlich herbeigeführte Weise beendet wurde. Damit hängt auch die Revision der Grundrissanordnung der Fundstelle zusammen, die in der aktuellen Darstellung eine Mischung aus der älteren wahllos angeordneten Bergbausiedlung und des regelmäßigen Grundrisses der jüngeren Lokationsstadt ist.

Mgr. Petr Nový, Středočeské muzeum v Roztokách u Prahy, Zámek 1, 25263 Roztoky, Česká republika, novy@muzeum-roztoky.cz 
